\title{
REVIEW
}

\section{Methotrexate-related pulmonary complications in rheumatoid arthritis}

\author{
Pilar Barrera, Roland F J M Laan, Piet L C M van Riel, P N Richard Dekhuijzen, \\ Agnes M Th Boerbooms, Levinus B A van de Putte
}

\begin{abstract}
Methotrexate (MTX) was described as a drug in $1946^{1}$ and first used in the treatment of human disease (childhood leukaemia) in 1948. ${ }^{2}$ Successful MTX treatment for rheumatoid arthritis (RA) and psoriasis was reported in $1951,{ }^{3}$ although the interest in this drug at that time was probably overshadowed by the impressive results of cortico-steroid treatment until approximately 1980 . MTX was approved by the food and drug administration (FDA) for the treatment of severe and disabling psoriasis in 1971 and for RA only in 1988. ${ }^{4}$

MTX-related pulmonary toxicity was first observed during treatment of childhood leukaemia in $1969^{5}$ and later in malignancies, ${ }^{67}$ psoriasis $^{67}$ and polymyositis. $^{78}$ Though it was postulated that pulmonary toxicity would appear only with a weekly dose higher than $20 \mathrm{mg}{ }^{7}$ this did not prove to be true when in 1983 pneumonitis was also reported during low-dose MTX treatment for RA. ${ }^{910}$
\end{abstract}

\section{Infectious and non infectious pulmonary complications}

In recent years there has been an increase in the number of reports of pulmonary complications associated with low-dose methotrexate therapy for rheumatic and nonrheumatic diseases including both non infectious and infectious pathology. Among the non infectious complications observed in patients with $R A$, interstitial pneumonitis has been most often reported ${ }^{7-13}$ (more than 35 cases since the first reports in 1983)..$^{10}$ Interstitial lung fibrosis has been observed during MTX treatment for RA, malignancies and psoriasis. $^{613}$ Furthermore, one case of accelerated pulmonary nodulosis ${ }^{14}$ and one of drug-induced asthma ${ }^{15}$ have so far been described during MTX treatment for RA. Lung fibrosis and nodulosis may be pulmonary manifestations of $\mathrm{RA},{ }^{16}$ and it is therefore difficult to ascribe this pathology only to MTX treatment. Two other complications, so far only observed during treatment with MTX in malignant diseases, are pulmonary oedema ${ }^{17-18}$ and isolated pleuritis. ${ }^{19}$

Among the pulmonary infections during MTX treatment of RA, the most frequently reported has been Pneumocystis carinii pneumonia with more than eight cases published since $1983 .^{20-25}$ Less frequently observed infections include pulmonary cryptococ- cosis, ${ }^{26}{ }^{27}$ aspergillosis, ${ }^{28}{ }^{29}$ disseminated histoplasmosis, ${ }^{28}$ parainfluenza virus infection ${ }^{12}$ and cytomegalovirus pneumonia. ${ }^{30}$ Pulmonary candidiasis was described in one patient with polymyositis/dermatomyositis treated with $\mathrm{MTX}^{31}$ but, to our knowledge, not in RA. Although some of the reported infections appeared during concomitant treatment with corticosteroids, these studies suggest a potential immunosuppressive effect of lowdose MTX treatment at least in some patients. The present review will focus on MTXpneumonitis.

\section{Pathogenesis}

The mechanism of MTX-induced lung pathology remains unclear. Lung damage due to folate deficiency has been suggested ${ }^{32}$ but seems unlikely since MTX pneumonitis may occur after a single MTX dose $\mathrm{s}^{33}$ and is not prevented by folinic acid treatment. ${ }^{35}$ A hypersensitivity reaction is suggested by findings in lung biopsies: interstitial pneumonitis, granuloma formation and bronchiolitis, ${ }^{7}$ and in brochoalveolar lavage: lymphocytic alveolitis, increased eosinophils and reversed CD4/CD8 ratio, ${ }^{36}{ }^{37}$ together with the clinical findings of fever, peripheral eosinophilia and response to corticosteroids. The reports of spontaneous remission during MTX treatment ${ }^{7}$ and rechallenge of the drug without recurrence of lung pathology ${ }^{13}$ argue more for an idiosyncratic reaction than for hypersensitivity. A specific cellular immune reaction to the drug has been suggested by the production of a lymphokine which inhibits leukocyte migration [leukocyte inhibitor factor (LIF)] by peripheral blood lymphocytes after incubation with MTX. LIF production was observed in patients with MTX pneumonitis but not in other patients treated with MTX or healthy controls. ${ }^{38}{ }^{39} \mathrm{~A}$ toxic drug reaction is suggested by the accumulation of MTX in lung tissue, ${ }^{40}$ the biopsy findings of alveolar and non-specific lung injury, ${ }^{6}$ and the resolution of pathology after stopping or lowering the drug. ${ }^{41}$ The fact that pulmonary pathology does not appear to be related to cumulative MTX dose argues, against this hypothesis.

\section{Risk factors}

Age, sex, and disease duration are not associated with the development of MTXpneumonitis. This complication has been 
observed after oral, ${ }^{41}$ intravenous, ${ }^{42}$ intramuscular, ${ }^{41}$ intrathecal ${ }^{43}$ and even local $^{34}$ administration of MTX. No correlation has been found between the occurrence of lung toxicity and cumulative or weekly dose or dosage schedule. ${ }^{13}$ Pneumonitis has been observed after as little as $12.5 \mathrm{mg} \mathrm{MTX}^{33} 34$ and may appear even weeks after discontinuation of treatment. ${ }^{4-46}$ In view of the relative rarity of MTX pneumonitis in other non-malignant diseases like psoriasis ${ }^{47}$ and bronchial asthma, ${ }^{48}$ a propensity to pulmonary involvement in RA has been suggested ${ }^{33}$ but so far comparative studies on the incidence of MTX-pneumonitis in RA and other diseases are lacking. A possible relationship between certain HLA haplotypes and increased risk for MTX-pneumonitis has been mentioned in two previous reports: DRw3 in one case ${ }^{33}$ and A2,24;DR4 in two cases. ${ }^{49}$ We also observed the HLA DR4 haplotype in four of five patients with MTX-related lung toxicity admitted to our unit during 1993, but studies in larger patient groups are needed.

Renal function impairment ${ }^{1350}$ and concomitant use of non steroidal anti-inflammatory drugs ${ }^{12}$ have been suggested to predispose to MTX-toxicity in some studies but this has not been confirmed by others. ${ }^{51}$ Specific risk factors for the development of MTX pneumonitis are not known exactly but some studies have suggested that a history of smoking, ${ }^{12}$ pre-existing pulmonary disease $^{125253}$ and abnormal chest radiographs before MTX institution ${ }^{53}$ might be predisposing factors.

\section{Diagnosis}

The diagnosis of MTX-pneumonitis is difficult since there are no pathognomonic findings and this condition may mimic other pulmonary diseases. When a patient treated with MTX develops new respiratory symptoms, the differential diagnosis includes MTXpneumonitis, rheumatoid lung disease, and pulmonary infection or emboli. Exclusion of other pathology, particularly of infectious origin, is time consuming and therefore MTXpneumonitis is often diagnosed retrospectively. Criteria, proposed by two different groups, ${ }^{12}{ }^{13}$ (table 1) are helpful for diagnostic purposes, but the term 'definite' MTX-pneumonitis ${ }^{12}$ should be avoided in view of the presumptive character of the diagnosis. ${ }^{13}$ The incidence of abnormalities in clinical, laboratory and radiological examination in patients with MTX-pneumonitis is difficult to estimate since this complication is relatively uncommon and large patient series are lacking. Data presented in the following sections were deducted from previous studies.

\section{Clinical features and physical examination}

The most usual complaints include dyspnoea and fever..$^{9-13}$ Non productive cough has been reported in $75 \%$ of the patients. ${ }^{54}$ Pleuritic chest pain may also be present but is rare. ${ }^{13} 19$ In most patients a subacute clinical course is observed during some weeks, but acute presentations have been also described. ${ }^{33}$ On examination, tachypnoea (in $38-52 \%$ of the patients), crepitant rales (in $31-45 \%$ of the patients) and cyanosis (in $52 \%$ of the patients) are common findings. ${ }^{79-1354}$ Abnormalities on auscultation may be disproportionately scarce compared with the extensive radiological findings. ${ }^{33}$

\section{Laboratory investigations}

As for the clinical findings and physical examination, no specific results of laboratory tests are diagnostic for MTX-pneumonitis. Hypoxaemia is observed in $90-95 \%$ of the cases. $^{79-1354}$ The white blood cell count may be normal ${ }^{7}$ or show moderate leukocytosis without left shift. ${ }^{13}$ Mild eosinophilia has been reported in $41 \%$ of the patients ${ }^{74}$ and elevated levels of lactate dehydrogenase $(\mathrm{LDH})^{10}{ }^{13}$ have been reported.

Investigations directed to exclude infectious pathology should consist of extensive cultures of sputum, blood and bronchoalveolar lavage (BAL) fluid and serological test for common respiratory viruses, mycoplasma, rickettsia and legionella. Microscopical examination of BAL fluid is recommended to exclude Pneumocystis carinii, fungi and mycobacteria. BAL cell analysis usually reveals hypercellularity and lymphocytosis. ${ }^{36} 37$ Mild eosinophilia ${ }^{36}$ or neutrophilia ${ }^{37}$ and increased percentages of either $\mathrm{CD}^{36}$ or CD8 lymphocytes ${ }^{37}{ }^{38}$ have also been reported. The diagnostic value of BAL cell analysis is limited since lymphocytosis, increases in $\mathrm{CD} 4$ and decreases in

Table 1 Diagnostic criteria of MTX-pneumonitis

\begin{tabular}{|c|c|c|}
\hline & Searles et al $1987^{12}$ & Carson et al $1987^{13}$ \\
\hline Clinical & 1 Acute onset of dyspnoea & $\begin{array}{l}1 \text { Course consistent with a hypersensitivity } \\
\text { reaction }\end{array}$ \\
\hline Laboratory & $\begin{array}{l}2 \text { Fever }>38^{\circ} \mathrm{C} \\
3 \text { Tachypnoea } \geq 28 / \mathrm{min} \text { and nonproductive cough } \\
\left.4 \text { WBC } \leq 15,000 \times 10^{9} / 1 \text { ( } \pm \text { eosinophilia }\right)\end{array}$ & $\begin{array}{l}2 \text { Exclusion of infection and other pulmonary } \\
\text { disease }\end{array}$ \\
\hline & $\begin{array}{l}5 \mathrm{PO}_{2} \text { on room air }<55 \mathrm{~mm} / \mathrm{Hg} \text { at admission } \\
6 \text { Negative blood and sputum cultures (obligatory) }\end{array}$ & \\
\hline $\begin{array}{l}\text { Radiological } \\
\text { Pulmonary function tests }\end{array}$ & $\begin{array}{l}7 \text { Pulmonary interstitial or alveolar infiltrates } \\
8 \text { Restrictive pattern, decreased diffusion }\end{array}$ & 3 Infiltrates \\
\hline Histopathology & $\begin{array}{l}9 \text { Bronchiolitis/interstitial pneumonitis with giant cells } \\
\text { without evidence of pathogenic micro-organisms }\end{array}$ & 4 Consistent with drug-induced injury \\
\hline $\begin{array}{l}\text { Classification } \\
\text { Definite } \\
\text { Probable } \\
\text { Possible }\end{array}$ & $\begin{array}{l}6 \text { out of } 9 \text { criteria } \\
5 \text { out of } 9 \text { criteria } \\
4 \text { out of } 9 \text { criteria }\end{array}$ & $\begin{array}{l}\text { not used } \\
\geq 3 \text { out of } 4 \text { criteria } \\
2 \text { out of } 4 \text { criteria }\end{array}$ \\
\hline
\end{tabular}


CD8 lymphocytes may be present in patients with RA (not treated with MTX) even in the absence of rheumatoid lung disease. ${ }^{55}$ Furthermore, similar findings and increased percentage of eosinophils have been observed during hypersensitivity pneumonitis induced by other antirheumatic drugs like gold, D-penicillamine, non-steroidal anti-inflammatory drugs and more rarely azathioprine and sulphasalazine. ${ }^{1655}$

\section{Radiological and scintigraphic examinations}

A great variety of chest $x$ ray patterns have been described but bilateral interstitial (in $50 \%$ of the patients) or mixed interstitial and alveolar infiltrates (in $41 \%$ of the patients), most prominent at the lung basis are probably the most common. ${ }^{913}{ }^{54}$ Unilateral infiltrates, ${ }^{1357} \mathrm{a}$ reticulonodular pattern ${ }^{58}$ and more rarely pleural effusions ${ }^{19}$ and transient hilar lymphadenopathy ${ }^{75}$ have also been reported. High-resolution computer tomography may show parenchymal ground-glass opacities (alveolitis), granulomas and fibrosis. ${ }^{59-61}$ Gallium-67 62 and Tc-99 diethylenetriamine-pentacetate (DTPA) lung scintigraphy $^{64}$ may show increased pulmonary uptake. These are sensitive but non-specific investigations in drug-induced lung disease and their value in the diagnosis and follow up of lung pathology related to MTX or other drugs has yet to be determined.

\section{Pulmonary function tests}

Apart from hypoxaemia, thorough pulmonary function evaluation during MTX-pneumonitis has not often been reported. Restrictive and obstructive patterns and low CO diffussion capacity $^{72}$ have been observed. So far uncomplicated long term treatment with low dose MTX has not been associated with deterioration in pulmonary function. ${ }^{65-67}$

\section{Lung biopsy}

This procedure has been recommended not only for histopathological examination but also to exclude other diseases, especially infections. Before performing a lung biopsy, the clinician should balance the condition of the individual patient against the morbidity and mortality ${ }^{68}$ associated with such a procedure. In some studies, patients have been managed without pathological examination of lung tissue. ${ }^{13}$ Transbronchial biopsy may be adequate in establishing the diagnosis, ${ }^{57}$ but if inconclusive, open lung biopsy may be required. ${ }^{101369}$ The pathological findings of interstitial pneumonitis with lymphocytic 9101357 and sometimes eosinophilic ${ }^{41}{ }^{57}$ infiltration, bronchiolitis and granuloma formation ${ }^{9} 1057$ resemble other forms of hypersensitivity pneumonitis and have lead to the classification of MTX-pneumonitis as a hypersensitivity reaction. Alveolar damage with hyaline membranes and type 2 alveolar cell hyperplasia and dysplasia ${ }^{57}$ may also be present. Interstitial fibrosis ${ }^{79} 1013$ has been described but this may be observed also in uncomplicated RA. ${ }^{13}$ Electron microscopy examination reveals intact basement membranes and proliferation and desquamation of lymphocytes and eosinophils. ${ }^{7}$

\section{Treatment and outcome}

The therapy for MTX-pneumonitis has not been analysed in controlled trials and experience is based on case reports. Besides supportive therapy, withdrawal of MTX seems a logical approach though resolution of pulmonary pathology despite continuation of MTX treatment has been reported. ${ }^{51}$ Reinstitution of MTX treatment after MTXrelated lung toxicity has been reported in five cases without event ${ }^{7} 121370$ but recurrence of pulmonary complications may occur. ${ }^{13} 71$ Though improvement without corticosteroids has been reported, ${ }^{134158}$ this therapy might hasten recovery ${ }^{10} 1357$ and is recommended in high dose until clinical improvement is evident. No worsening of MTX-pneumonitis has yet been observed when the dose of steroids is tapered. There is no evidence that corticosteroids or folinic acid prevent MTXrelated pulmonary disease. ${ }^{35}$ Effective treatment with daunorubicine in three leukaemia patients with MTX-pneumonitis has been reported $^{72}$ but, for evident reasons, this drug has not been used in non malignant diseases. In some cases (that is, when lung biopsy is not performed), additional antibiotic treatment may be warranted in view of the difficult exclusion of some pulmonary infections. Empirical treatment for Pneumocystis carinii should be considered in such patients. The outcome of MTX-pneumonitis is usually favourable with clinical amelioration usually preceeding radiological and functional improvement. ${ }^{7} 1257$ However, fatal outcome has been described in both rheumatic ${ }^{757} 58$ and non-rheumatic ${ }^{78}$ diseases.

\section{Prevalence in the literature and review of own experience}

Data about the prevalence of MTXpneumonitis in RA show a great variation. While in some large studies ${ }^{73}{ }^{74}$ such pathology was not observed at all, several retrospective and prospective studies have reported prevalence rates between 0.3 and $11.6 \%$ (table 2). ${ }^{7}{ }^{11-13} 49$ 75-83 The incidence of MTXpneumonitis is not mentioned in most studies. Carson et al $^{13}$ observed 3.9 cases per 100 patient years of MTX therapy in a retrospective study including 163 patients. The prospective ARAMIS programme reported incidence rates of dyspnoea and wheezing of respectively six and two per 1000 patient years among 497 patients treated with MTX, the incidence of MTX pneumonitis was not mentioned in this study. ${ }^{84}$ In our centre, lowdose MTX treatment for RA, systemic sclerosis (SS) and ankylosing apondylitis (AS) has been used since 1984, 1988, and 1992, respectively. Up to this year, sporadic cases of MTX-related pulmonary toxicity (see below) 
Table 2 Prevalence of MTX pneumonitis in the literature

\begin{tabular}{lllllll}
\hline Author & $\begin{array}{l}\text { Publication } \\
\text { year }\end{array}$ & Study design & $\begin{array}{l}\text { Observation } \\
\text { years }\end{array}$ & $\begin{array}{l}\text { Number cases/ } \\
\text { Total number } \\
\text { patients }\end{array}$ & Prevalence & Reference \\
\hline Sostman & 1976 & retrospective & 7 & $7 / 92$ & $7 \cdot 6 \%$ & 7 \\
St Clair & 1985 & retrospective & not mentioned & $3 / 95$ & $3 \cdot 1 \%$ & 57 \\
Cannon & 1986 & retrospective & not mentioned & $5 / 127$ & $3 \cdot 9 \%$ & 75 \\
Carson & 1987 & retrospective & 8 & $9 / 163$ & $5 \cdot 5 \%$ & 13 \\
Gispen & 1987 & retrospective & 3 & $1 / 72$ & $1 \cdot 4 \%$ & 58 \\
Searles & 1987 & retrospective & 8 & $4 / 73$ & $5 \cdot 5 \%$ & 12 \\
Alarcon & 1989 & retrospective & 5 & $2 / 152$ & $1 \cdot 3 \%$ & 76 \\
Scully & 1991 & retrospective & 5 & $11 / 124$ & $8 \cdot 8 \%$ & 77 \\
Hargreaves & 1992 & retrospective & 3 & $5 / 43$ & $11 \cdot 6 \%$ & 11 \\
Buchbinder & 1993 & retrospective & 5 & $2 / 587$ & $0 \cdot 3 \%$ & 78 \\
Boh & 1986 & prospective & 2 & $3 / 59$ & $5 \cdot 1 \%$ & 79 \\
Andersen & 1987 & prospective & not mentioned & $1 / 40$ & $2 \cdot 5 \%$ & 80 \\
Haranhan & 1989 & prospective & 4 & $1 / 128$ & $0 \cdot 8 \%$ & 81 \\
Drosos & 1990 & prospective & 2 & $1 / 137$ & $0 \cdot 7 \%$ & 82 \\
Kremer & 1992 & prospective & $7 \cdot 5$ & $2 / 29$ & $6 \cdot 9 \%$ & 49 \\
Weinblatt & 1992 & prospective & 7 & $2 / 26$ & $7 \cdot 7 \%$ & 83 \\
\hline
\end{tabular}

were observed. In contrast, in 1993 such pathology appeared in five patients within a period of three months, and at least four of these cases satisfied the criteria of MTX pneumonitis. ${ }^{12}{ }^{13}$ Apart from this cluster of five cases, we performed a review among more than 220 patients $^{29}{ }^{71}{ }^{85-90}$ enrolled in prospective studies with low-dose MTX (table 3) and all hospital admissions to our unit, from 1984 to 1993, where pulmonary pathology was recorded. Eight additional cases of MTXrelated pulmonary pathology were identified consisting of four episodes of MTXpneumonitis (two in the same patient ${ }^{71}$ ) and four pulmonary infections. The latter encompassed two cases of viral pneumonitis (one of them during leukopenia ${ }^{87}$ ), one case of pulmonary aspergillosis ${ }^{29}$ and one case of pneumococcal pneumonia during leukopenia. Including the five patients observed during 1993, we have therefore observed 13 cases of MTX-related pulmonary pathology in the past nine years.

\section{Conclusion}

This review of the literature and our own experience shows that, though probably uncommon, pulmonary pathology related to low-dose MTX treatment for rheumatic diseases has been well documented.

There are no pathognomonic clinical, laboratory or radiological features which allow differentiation between infectious and noninfectious pathology except for the isolation of a pathogenic micro-organism. To achieve this goal, transbronchial or open lung biopsy have been recommended, but the risks inherent to these procedures should be taken into account, especially in patients with a poor pulmonary condition. Our approach to a patient with suspected MTX-related lung pathology consists of: MTX discontinuation, supportive therapy, comprehensive diagnostic procedures to exclude infection (including BAL analysis), empirical antimicrobial treatment and, in some cases, intravenous corticosteroids until clinical and radiological improvement appears. This approach is warranted as excluding infection is difficult, time consuming and sometimes retrospective.

Though no predisposing factors for the development of MTX pneumonitis are known, abnormalities on chest radiographs and pulmonary pathology previous to MTX treatment have been suggested to increase the risk of pulmonary toxicity. For this reason and also to exclude underlying rheumatoid lung disease, chest radiographs should be performed before institution of MTX treatment. Uneventful MTX-treatment is not associated with deterioration in pulmonary function, therefore in our practice, pretreatment pulmonary function tests and blood gas analysis are selectively performed in patients with a history of lung pathology.

Since MTX-related lung toxicity is potentially fatal, patients should be instructed to report any new pulmonary symptoms without delay.

We thank F H J van den Hoogen, P J S M Kerstens, C J Haagsma and M C W Creemers for their clinical studies. We are also grateful to $P$ Donnelly and J W $M$ van der Meer for are also grateful to $P$ Donnelly
the revision of this manuscript.

1 Angier R B, Boothe J W, Hutchings B L. The structure and synthesis of the liver L. Casei factor. Science 1946; 103: 667-9.

2 Farber S, Diamond L K, Mercer R D, Sylvester R F Jr, Solff $\mathrm{J}$ A. Temporary remission in acutet leukemia in children produced by folic antagonist 4-aminopteroyl-glutamic acid (aminopterin). N Engl F Med 1948; 238: 787-93.

3 Gubner R, August S, Ginsberg V. Therapeutic suppression of tissue reactivity II. Effect of aminopterin in rheumatoid of tissue reactivity II. Effect of aminopterin in rheumatoid
arthritis and psoriasis. $A m \mathcal{F} M e d S c i$ 1951; 221: 176-82.

4 Tugwell P, Bennett K, Bell M, Gent M. Methotrexate in rheumatoid arthritis. Feedback on American College of Physicians Guidelines. Ann Int Med 1989; 110: 581-3.

5 Acute Leukemia Group B. Acute lymphocytic leukemia in children. Maintenance therapy with methotrexate administered intermittently. $\mathcal{F}$ Am Med Assoc 1969; 207: 923-8.

Table 3 Prospective studies with low-dose MTX treatment in our centre

\begin{tabular}{|c|c|c|c|c|c|c|c|}
\hline Number & Patient population & Study design & Follow up time & $\begin{array}{l}\text { Follow up months } \\
\text { per patient }\end{array}$ & $\begin{array}{l}\text { Number of } M T X \\
\text { treated patients }\end{array}$ & $\begin{array}{l}\text { MTX-related pulmonary } \\
\text { pathology number of cases }\end{array}$ & Reference \\
\hline $\begin{array}{l}1 \\
2 \\
3\end{array}$ & $\begin{array}{l}\text { Refractory RA } \\
\text { Follow up of number } 1 \\
\text { RA }\end{array}$ & $\begin{array}{l}\text { Open } \\
\text { Open } \\
\text { Double-blind } \\
\text { MTX versus AZA }\end{array}$ & $\begin{array}{l}1984-86 \\
1986-92 \\
1986-88\end{array}$ & $\begin{array}{l}12 \\
72 \\
12\end{array}$ & $\begin{array}{l}16 \\
12 \\
31\end{array}$ & $\begin{array}{l}0 \\
0 \\
1 \text { viral pneumonitis } \\
1 \text { suspected viral pneumonitis }\end{array}$ & $\begin{array}{l}85 \\
86 \\
87\end{array}$ \\
\hline $\begin{array}{l}4 \\
5\end{array}$ & $\begin{array}{l}\text { Follow up of number } 3 \\
\text { RA }\end{array}$ & $\begin{array}{l}\text { Open } \\
\text { Open } \\
\text { MTX versus MTX + SASP }\end{array}$ & $\begin{array}{l}1988-92 \\
1991-92\end{array}$ & $\begin{array}{l}48 \\
6\end{array}$ & $\begin{array}{l}25 \\
40\end{array}$ & 2 MTX pneumonitis & $\begin{array}{l}71 \\
88\end{array}$ \\
\hline 6 & RA & $\begin{array}{l}\text { Double blind } \\
\text { MTX versus SASP } \\
\text { versus MTX + SASP }\end{array}$ & 1992 (ongoing) & 12 & $90^{\star}$ & 0 & \\
\hline 7 & RA & Open & $1990-92$ & 12 & 20 & 0 & \\
\hline 8 & Early RA & Open & 1985 (ongoing) & & 67 & 0 & 89 \\
\hline 9 & Systemic sclerosis & Open & $1988-89$ & 12 & 8 & 1 Pulmonary aspergillosis & 29 \\
\hline 10 & Systemic sclerosis & $\begin{array}{l}\text { Double blind } \\
\text { MTX versus Placebo }\end{array}$ & $1989-92$ & 12 & 28 & 0 & 90 \\
\hline 11 & Ankylosing spondylitis & Open & $1992-93$ & 9 & 13 & 0 & \\
\hline
\end{tabular}

*: ongoing study, 90 patients enrolled, treatment code has not been broken yet.

AZA: azathioprine, SASP: sulphasalazine ${ }^{69}: 2$ episodes of MTX pneumonitis presented in the same patient. 
6 Bedrossian C W M, Miller W C, Luna M A. Methotrexateinduced diffuse interstitial pulmonary fibrosis. Southern Med F 1979; 72: 313-8.

7 Sostman H D, Matthay R A, Putman C E, Walker-Smith G J. Methotrexate-induced pneumonitis. Medicine 1976; 55: $371-88$.

8 Dickley B F, Myers A R. Pulmonary disease in polymyositisdermatomyositis. Sem Arthritis Rheum 1984; 14: 60-76.

9 Cannon G W, Ward J R, Clegg D O, Samuelson C O, Abbott T M. Acute lung disease associated with low-dose pulse metho-trexate therapy in patients with rheumatoid arthritis. Arthritis Rheum 1983; 26: 1269-74.

10 Engelbrecht J A, Calhoon S L, Scherrer J J. Methotrexate pneumonitis after low-dose therapy for rheumatoid pneumonitis after low-dose therapy for
arthritis. Arthritis Rheum 1983; 26: 1275-8.

11 Hargreaves $M$ R, Mowat A G, Benson M K. Acute pneumonitis associated with low dose methotrexate treatment for rheumatoid arthritis: report of five cases and review of published reports. Thorax 1992; 47: 628-33.

12 Searles G, McKendry R J R. Methotrexate pneumonitis in rheumatoid arthritis: potential risk factors. Four case reports and a review of the literature. I Rhcumatol 1987 14: $1164-71$.

13 Carson C W, Cannon G W, Egger M J, Ward J R, Clegg D O. Pulmonary disease during treatment of rheumatoid arthritis with low dose pulse methotrexate. Scmin Arthritis Rheum 1987; 16: 186-95.

14 Alarcon G S, Koopman W J, McCarty M J. Nonperipheral accelerated nodulosis in a methotrexate-treated accelerated nodulosis in a methotrexate-treated
rheumatoid arthritis patient. Arthritis Rhellm 1993; 36: rheumatoi

15 Jones G, Mierins E, Karsh J. Methotrexate-induced asthma. Am Rev Respir Dis 1991; 143: 179-81.

16 Cannon G W. Pulmonary complications of antirheumatic drug therapy. Semin Arthritis Rheum 1990; 19: 353-64.

17 Bernstein M L, Sobel D B, Wimmer R S. Noncardiogenic pulmonary edema following injection of methotrexate into the cerebrospinal fluid. Cancer 1982; 50: 866-8.

18 Lascari A D, Strano A J, Johnson W W, Collins J G P. Methotrexate-induced sudden fatal pulmonary reaction. Cancer 1977; 40: 1393-7.

19 Walden P A M, Mitchell-Heggs P F, Coppin C, Dent J Bagshawe J D. Pleurisy and methotrexate treatment. $B M \mathcal{F}$ Bagshawe J D

20 Perruquet J L, Harrington T M, Davis D E. Pneumocystis carinii pneumonia following methotrexate therapy for rheumatoid arthritis (letter). Arthritis Rheum 1983; 26 1291-2.

21 Wollner A, Mohle-Boetani J, Lambert R E, Perruquet J L, Raffin T A, McGuire J L. Pneumocystis carinii pneumonia complicating low dose methotrexate treatment for rheumatoid arthritis. Thora. 1991; 46 $205-7$.

22 Flood D A, Chan C K, Pruzanski W. Pneumocystis carinii pneumonia associated with methotrexate therapy in rheumatoid arthritis. $\mathcal{F}$ Rheumatol 1991; 18: 1254-6.

23 Leff R L, Case J P, McKenzie R. Rheumatoid arthritis, methotrexate therapy and pneumocystis carinii methotrexate therapy and pneumocystis
pneumonia (letter). Ann Int Med 1990; 112: 716

24 Lang B, Riegel W, Peters T, Peter H H. Low dose methotrexate therapy for rheumatoid arthritis complicated by pancytopenia and Pneumocystis carini pneumonia. F Rheumatol 1991; 18: 1257-9

25 Shiroky J B, Frost A, Skelton J D, Haegert D G, Newkirk M M, Neville C. Complications of immunosuppression associated with weekly low dose methotrexate. $\mathscr{f}$ Rheumatol 1991; 18: 1172-5.

26 Altz Smith M, Kendall L G Jr, Stamm A M. Cryptococcosis associated with low-dose methotrexate for arthritis. $A m \mathcal{F}$ Med 1984; 83: 179-81.

27 Law K F, Aranda C P, Smith R L, Berkowitz K A, Ittman M M, Lewis M. Pulmonary cyptococcosis mimicking methotrexate pneumonitis. 7 Rheumatol $1993 ; 20: 872-3$.

28 Erikson N, Furst D E. Significant methotrexate (MTX) toxicity in RA patients: Results of an ongoing longterm toxicity in RA patients: Results of an ongoing
prospective trial. Arthritis Rheum 1987; 30: S59.

29 Van den Hoogen F H J, Boerbooms A M Th, van de Putte L B A, Rasker J J, van Venrooij W J. Low dose methotrexate treatment in systemic sclerosis (letter). $\mathcal{F}$ Rheumatol 1991; 18: 1763-4

30 Clerc D, Brousse C, Mariette X, Bennet P, Bisson M Cytomegalovirus pneumonia in a patient with rheumatoid arthritis treated with low dose methotrexate and prednisone (letter). Ann Rheum Dis 1991; 50: 67.

31 Dickey B F, Myers A R. Pulmonary disease in polymyositis/ dermatomyositis. Sem Arthritis Rheum 1984; 14: 60-76.

32 Drug and poison-induced pulmonary disease. In: Fraser $\mathrm{R}$ G, Paré J A P, Paré P D, Fraser R S, eds. Diagnosis of disease of the chest. Philadelphia: W B Saunders, 1991: 4: $2433-4$

33 Ridley M G, Wolfe C S, Mathews J A. Life threatening acute pneumonitis during low dose methotrexate treatment for rheumatoid arthritis: a case report and review of the literature. Ann Rheum Dis 1988; 47: 784-8.

34 Schoenfeld A, Mashiach R, Vardy M, Ovadia J Methotrexate pneumonitis in nonsurgical treatment of ectopic pregnancy. Obstetrics Gynaecologv 1992; 80 $520-1$

35 Batist G, Andrews Jr J L. Pulmonary toxicity of antineoplastic drugs. F Am Med Assoc 1981; 246: $1149-53$.

36 White D A, Rankin J A, Stover D E, Gellene R A, Gupta S. Methotrexate pneumonitis. Bronchoalveolar lavage findings suggest an immunologic disorder. Am Rev Respir Dis 1989; 139: 18-21.
37 Akoun G M, Mannaud C M, Touboul J L, Denis M F Milleron B J, Perrot J Y. Use of bronchoalveolar lavage Milleron B J, Perrot J Y. Use of bronchoalveolar lavage in the evaluation

38 Akoun G M, Gauthier-Rahman S, Maynaud C M, Touboul $\mathrm{J} L$, Denis $M$ F. Leukocyte migration inhibition in methotrexate-induced pneumonitis. Evidence for an immunologic cell-mediated mechanism. Chest 1987; 91: $96-9$.

39 Suzuki K, Rahman S G, Akoun G M. Leukocyte migration inhibition test in drug-induced pneumonitis. NipponKvobu-Shikkan-Gakai-Zasshi 1992; 30: 76-81.

40 Anderson L L, Collins G J, Ojima Y. A study of the distribution of me-thotrexate in human tissues and tumors. Cancer Res 1970; 30: 1344-8.

41 Clarysse A M, Cathey W J, Cartwright G E, Wintrobe M M. Pulmonary disease complicating intermittent therapy with methotrexate. F Am Med Assoc 1969; 209: 1861 4.

42 Arnett F C, Whelton J C, Zizic T M. Stevens M B. Methotrexate therapy in polymyositis. Ann Rhemm Dis 1973; 32: $536-46$.

43 Gutin P H, Green M R, Blever W A, Bauer V L, Wiernik $\mathrm{P} \mathrm{H}$, Walker M D. Methotrexate pneumonitis induced by intrathecal methotrexate therapy. (iancer 1976; 38: $1529-34$.

44 Elsasser S, Dalquen P, Soler M, Perruchoud A P. Methotrexate-induced penumonitis: appearance four weeks after discontinuation of treatment. Am $R_{i 2} R_{i s p i r}$ Dis 1989; 140: 1089-9?

45 Pourel J, Guillemin F, Fener P, Webanck L, Bene M C, Delorme $\mathrm{N}$. Delaved methotrexate pneumonitis in rheumatoid arthritis (letter). F Rhemmatol 1991; 18: 303-4.

46 De Bandt M, Rat A C, Palazzo E, Kahn M F. Delayed methotrexate pneumonitis (letter). F Rhcumatol 1991; 18: 1943

47 Hughes G R V. Methotrexate in rheumatoid arthritis. Am Rheum Dis 1990; 49: 275.

48 Tsai J J, Shin J F, Chen C H, Wang S R. Methotrexate pneumonitis in bronchial asthma. Int Arch Allorgy Immumol 1993; 100: 287-90

49 Kremer J M, Phelps C. Long-term prospective study of the use of methotrexate in the treatment of rheumatoid arthritis. Update after a mean of 90 months. Arthritis Rheum 1992; 35: 138-45.

50 McKendry R J R, Cyr M. Toxicity to methotrexate compared with azathio-prine in the treatment of compared with azathio-prine in the treatment of
rheumatoid arthritis. A case-control study of 131 patients. rheumatoid arthritis. A case-con
Arch Int Med 1989; 149: 685-9.

51 Rooney T W, Furst D E. Comparison of toxicity in methotrexate treated rheumatoid arthritis patients also taking aspirin or other NSAII). Arthritis Rheum 1986; 29: S76.

52 Bell M J, Geddic W R, Gordon D A, Reynolds W J. Preexisting lung disease in patients with rheumatoid arthritis may predispose

53 Golden M R, Katz R S, Balk R A, Neu J, Golden H. The relationship of pre-existing lung disease to the occurrence of methotrexate pneumonitis in rheumatoid arthritis. of methotrexate pneumonitis

54 Massin F, Coudert B, Marot J P, Foucher P, Camus Ph, Jeannin L. La pneumopathie du methotrexate. Re' Mal Resp 1990; 7: 5-15.

55 Kolarz G, Scherak O, Popp W, ct al. Bronchoalveolar lavage in rheumatoid arthritis. Br $\mathcal{F}$ Rhcumatol 1993; 32: $556-61$

56 Chabot F, Aymard B, Lesur O, it al. Drug-induced pulmonary diseases: diagnostic, therapeutic and prognostic aspects. A propos of 10 personal case reports. Rer Mal Respir 1992; 9: 593-601.

57 St Clair E W, Rice J R, Snyderman R. Pneumonitis complicating low-dose methotrexate therapy in
rheumatoid arthritis. Arch Intem Med 1985; 145: 2035-8.

58 Gispen J G, Alarcon G S, Johnson J J, Acton R T, Barger B O, Koopman W J. Toxicity to methotrexate in rheumatoid arthritis. $\mathcal{F}$ Rhelumatol 1987; 14: 74.9.

59 Padley S P, Adler B, Hansell D M, Muller N L. Highresolution computed tomography of drug induced disease. Clin Radiol 1992; 46: 232-6.

60 Hansell D M, Kerr I H. The role of high resolution computed tomography in the diagnosis of interstitial lung disease. Thorax 1991; 46: 77-84.

61 Diffuse lung disease. In: Naidich D P, Zerhouni E A, Siegelman S S, eds. Computed tomography and magnetic resonance of the thorax. New York: Raven Press Ltd, 1991 : 341-405.

62 Bisson G, Drapeau G, Lamoureux G, Cantin A, RolaPleszczynski $M$, Bégin R. Computer based quantitative analysis of gallium-67 uptake in normal and diseased lungs. Chest 1983; 84: 513-7.

63 Elstad M R. Lung biopsy, bronchoalveolar lavage and Gallium scanning. In: Cannon G W, Zimmerman G A, Gallium scanning. In: Cannon G W, Zimmerman G A,
eds. The lung and rhetumatic diseases. New York: Marcel Dekker, 1990: 117-42.

64 King T E. Idiopathic pulmonary fibrosis. In: King T E, Decker $\mathrm{B}$ C, eds. Interstitial lung diseasi. Toronto: Decker B C, eds. Interstitial

65 Jeurissen M E C, Boerbooms A M Th, Festen J, van de Putte L, B A, Doesburg W. Serial pulmonary function tests during a randomized, double-blind trial of azathioprine versus methotrexate in rheumatoid arthritis. Arthritis Rheum 1991; 34: S90.

66 Croock A D, Furst D F, Helmers R A, et al. Methotrexate does not alter pulmonary function in patients with rheumatoid arthritis. Arthritis Rheum 1989; 32: S60. 
67 Velay B, Lamboley L, Massonnet B. Prospective study of respiratory function in rheumatoid arthritis treated with methotrexate. Eur Respir f 1988; 1 (supp 2): $371 \mathrm{~S}$.

68 Gaensler E A, Carrington C B. Open lung biopsy for chronic diffuse infiltrative lung disease: Clinical, roentgenographic and physiological correlation in 502 patients. Ann Thorac Surg 1980; 30: 411-26.

69 Grubben M J A L, Kerstens P J S M, Wiersma J M, Boerbooms A M T, Festen J. Pleuro-pulmonary involvement in patients with connective tissue disease. The role of open lung biopsy. Neth $\mathcal{f}$ Med 1993; 43: 269-76.

70 Cook N J, Carroll G J. Successful reintroduction of methotrexate after pneumonitis in two patients with methotrexate after pneumonitis in two patients with

71 Kerstens P J S M, Van Loenhout J W A, Boerbooms A M Th, Van de Putte L B A. Methotrexate, pneumonitis and infection (letter). Ann Rheum Dis 1992; 51: 1179.

72 Pasquinucci G, Ferrara P, Castellari R. Daunorubicine treatment of metho-trexate pneumonia. $\mathcal{f} \mathrm{Am} \mathrm{Med} \mathrm{Assoc}$ 1971; 216: 2017.

73 Furst D E, Erikson N, Clute L, Koehnke R, Burmeister L F, Kohler J A. Adverse experience with methotrexate during 176 weeks of a longterm prospective trial in parients with rheumatoid arthritis. $f$ Rheumatol $1990 ; 17$ patients

74 Weinstein A, Marlowe S, Korn J, Farouhar F. Low-dose methotrexate treatment of rheumatoid arthitis, long-term observations. Am ₹ Med 1985; 79: 331-7.

75 Cannon G W, Clegg D O, Samuelson Jr C O, Ward J R. Pulmonary toxicity during treatment of rheumatoid arthritis with methotrexate: prevalence, clinical features, treatment and follow up. Arthritis Rheum 1984; 27: S26

76 Alarcon G S, Tracy I C, Blackburn W D. Methotrexate in rheumatoid arthritis. Toxic effects as the major factor in limiting long-term treatment. Arthritis Rheum 1989; 32: 671-6.

77 Scully C J, Anderson C J, Cannon G W. Long-term methotrexate therapy for rheumatoid arthritis. Semin Arthritis Rheum 1991; 20: 317-31.

78 Buchbinder R, Hall S, Sambrook P N, et al. Methotrexate therapy in rheumatoid arthritis: a life table review of 587 therapy in rheumatoid arthritis: a life table R heumatol 1993 ; patients treated

79 Boh L E, Schuna A A, Pitterle M E, Adams E M, Sundstrom W R. Low-dose weekly oral methotrexate therapy for inflammatory arthritis. Clin Pharm 1986; 5: 503-8.

80 Andersen P A, West S G, Nordstrom D M. Toxicity of chronic therapy with pulse methotrexate in rheumatoid arthritis: potential increased risk of infection. Arthritis Rheum 1987; 30: S60.

81 Hanranhan P S, Scrivens G A, Russell A S. Prospective long term follow-up of methotrexate therapy in rheumatoid arthritis: toxicity, efficacy and radiological progression. $\mathrm{Br}$ f Rheum 1989; 28: 147-53.

82 Drosos A A, Psychos D, Andonopoulos A P, Stefani-Nikou S, Tsianos E B, Moutsopoulos H M. Methotrexate therapy in rheumatoid arthritis. A two year prospective follow up. Clin Rheumatol 1990; 9: 333-41.

83 Weinblatt $\mathrm{M}$ E, Weissman B N, Holdsworth D E D, et al. Long-term prospective study of methotrexate in the Long-term prospective study of methotrexate in the treatment of rheumatoid arthritis Rheum 1992; 35: 129-37.

84 Singh G, Fries J F, Williams C A, Zatarain E, Spitz, Bloch D A. Toxicity profiles of disease modifying antirheumatic drugs in rheumatoid arthritis. $\mathcal{F}$ Rheumatol 1991; 18: 188-94.

85 Boerbooms A M Th, Jeurissen M E C, Westgeest A A A Theunisse H, Van de Putte L B A. Methotrexate in refractory rheumatoid arthritis. Clin Rheumatol 1988; 7: 249-56.

86 Kerstens P, Boerbooms A, Brummelkamp E, van de Putte L. Methotrexate in refractory rheumatoid arthritis. Results after 4 years. Br $\mathcal{F}$ Rheumatol 1993; 32 (suppl 1) 115: 60 .

87 Jeurissen M E C, Boerbooms A M Th, Van de Putte L B $\mathrm{A}$, et al. Methotrexate versus azathio-prine in the treatA, et al. Methotrexate versus azathio-prine in the treatment of rheumatoid arthritis. A forty-eight randomized
double-blind trial. Arthritis Rheum 1991; 34: 761-72.

88 Haagsma C, van Riel P, van de Putte L. Combination therapy in RA: Sulphasalazine and methotrexate (abstract). Br $\mathcal{F}$ Rheumatol 1992; 31: 32.

89 Wijnands $M$ J H, van't Hof M A, van Leeuwen $M A$, van Rijswijk M H, van de Putte L B A, van Riel P L C M. Long-term second-line treatment: a prospective drug survival study. $B r \mathcal{F}$ Rheumatol 1992; 31: 253-8.

90 Van den Hoogen F H J, Boerbooms A M Th, van Lier H J J, van de Putte L B A. Methotrexate in systemic J J, van de Putte $\mathrm{L}$ A. Methotrexate in systemic sclerosis: preliminary 24 week results of a placebo S217. 